\title{
Assessment of quality of life in patients with advanced oral cancer who underwent mandibulectomy with or without bone reconstruction
}

\author{
Jose Roberto Netto Soares ${ }^{1}$ \\ Fernando Luiz Dias ${ }^{1}$ \\ Roberto Rego Monteiro de Araujo Lima ${ }^{1}$ \\ Ullyanov Bezerra Toscano ${ }^{1}$ \\ Ana Carolina Past Pontes ${ }^{1}$ \\ Ruiter Diego Botinelly ${ }^{1}$ \\ Fernanda Gonzalez Rocha Souza ${ }^{1}$ \\ Vergilius José Furtado de Araujo Filho ${ }^{2}$ \\ (iD) Leandro Luongo Matos ${ }^{2}$ \\ Claudio Roberto Cernea ${ }^{2}$
}

\begin{abstract}
1. Head and Neck Surgery Service - National Cancer Institute, Rio de Janeiro/RJ, Brasil 2. Discipline of Head and Neck Surgery, Faculty of Medicine, University of São Paulo, São Paulo/SP, Brasil
\end{abstract}

INTRODUCTION: Malignant neoplasms of the head and neck, due to its anatomical location, can cause significant alterations in vital functions related to feeding, communication and social interaction of the affected patients. Objective: To analyze the quality of life of patients with advanced malignant neoplasms of the oral cavity and submitted to radical operations with curative intent. Material and methods: 47 patients with oral cavity squamous cell carcinoma (SCC), in stages III and IV, underwent surgical treatment with segmental mandibulectomy and complementary radiotherapy. The patients were submitted to the quality of life questionnaires after a minimum time of six months after the surgical treatment. Results: Of the 183 patients, only $47(25.7 \%)$ were able to answer the questionnaire and were included as the sample of the study. The majority of patients selected were male (39; $82.9 \%)$. The mean age was 64.4 years. The majority of the patients presented clinical stage IV (83\%) and were submitted to adjuvant radiotherapy (95.4\%). The mean score obtained after the questionnaires were applied was 64.6. The worst scores were found in swallowing and chewing. Conclusion: There were no statistically significant differences in the domains of quality of life between the two groups studied (with bone reconstruction versus no bone reconstruction). Patients interviewed 2 years or more after treatment presented higher scores $(p=0.02)$. KEY-WORDS: Quality of life. Mouth neoplasms. Mandibular reconstruction. Carcinoma, squamous cell. Bone transplantation. Mandibular osteotomy.

\section{INTRODUCTION}

Oral cancer can compromise important individual abilities and aspects, such as speech, breath, appearance, and swallowing; Radical surgery can incur in severe physical changes in the patient due to, mainly, the extension of the surgical treatment. A considerable number of patients feel mutilated, stigmatized, and bothered by people's reaction. This can lead to stress and social isolation, with a need for functional and psychosocial rehabilitation. ${ }^{1,2}$ One of the biggest worries reported by patients is the disfigurement associated to the disease and extensive surgeries, in addition to the loss of major functions, especially those 
related to chewing and swallowing when there is the need of mandibular resection. ${ }^{3,4}$

Research on cancer patient's quality of life is essential to assess the areas affected by the disease and plan interventions to rehabilitate these patients. Thus, the purpose of this study was to assess the quality of life in patients with advanced malignant neoplasms in the oral cavity who underwent radical surgery with curative intent, comparing those who underwent functional reconstruction of the mandible to those who did not.

\section{MATERIAL AND METHODS}

This is a cross-sectional study that assesses the quality of life in oral cancer patients for a period of at least six months after ongoing surgical treatment. The study was approved by the Institutional Ethics Committee (protocol 058/2008), and all patients signed an Informed Consent Form.

Consecutive patients of both genders who were treated from 2004 to 2013 in a single tertiary institution were evaluated Those aged between 25 and 75 years, with stage III and IV squamous cell carcinoma of the oral cavity submitted to radical or reconstructive surgery were included. Patients who were actively sick at the moment when the questionnaires were applied were not included.

The Portuguese validated version of the University of Washington Quality of Life Questionnaire UWQOL was used. ${ }^{5}$ It comprises 12 questions related to specific functions of the head and neck, as well as others regarding activity, recreation, pain, mood, and anxiety. Each domain has three to five categories of answers, with scores varying from 0 (worst) to 100 (best), which were assessed in two ways: individually in each domain and the total score for all the domains, calculated as a composite score that is the average of all the 12 domains. There are also three generic questions that do not have a score of their own and are used as a basis for comparison between patients or groups of patients. The questionnaire was applied by a single trained evaluator.

\section{Statistical analysis}

A descriptive analysis of the selected population was performed using central tendency and dispersion for the continuous variables and frequency distribution for the categorical ones. All analyses were conducted with the help of the SPSS 20.0 software and a statistical significance of $5 \%(p<0.05)$ was adopted.

To assess the regular distribution of the outcome (quality of life score) and of the quantitative independent variables, the Kolmogorov-Smirnov was performed. A scatter plot was used to evaluate the linearity between the outcome and the independent variables. The Pearson correlation was used to test the collinearity of the qualitative independent variables.

The difference between each average score was calculated to assess the link between the independent variables and the quality of life scores, with the statistical difference obtained by means of analysis of variance. In order to identify the variables that would be included in the multiple linear regression model, a difference of seven points in the categories of each independent variable and/or the statistical significance were considered as clinically significant through the value of $\mathrm{p}<0.20$.

\section{RESULTS}

Initially, 183 patients were selected who met the inclusion criteria. A total of 47 (25.7\%) were submitted to an interview, thus forming the sample of the study.

At the time of the interview, the mean age was $61.8 \pm 8.4$ years, and the time between surgery and the time of the interview was 41.5 months. The most commonly affected place by the primary lesion was the floor of the mouth in 23 patients (49\%), followed by gingival margin in 16 patients (34.0\%). The patients who underwent combined surgery were reconstructed using myocutaneous flaps (72.3\%) or free flaps (27.7\%). Furthermore, 43 patients were classified as T4 $(80.9 \%)$, and there was node metastasis in 21 patients (44.7\%). The demographic and clinical characteristics of patients with advanced malignant neoplasms in the oral cavity included in this study are described in Table 1.

All the patients underwent mandibulectomy and were grouped according to the type of reconstruction used: in 34 patients $(72.3 \%)$ closure by synthesis or soft tissue flap reconstruction were used (Group 1); bone flap reconstruction (Group 2) was used in 13 cases (27.7\%).

The average score obtained after the assessment of the questionnaires was 64.6 (varying from 50 to 86.8). When stratified by type of reconstruction, the average was 65 in Group 1 and 63,1 in Group 2, both very similar. 
TABLE 1. DEMOGRAPHIC AND CLINICAL CHARACTERISTICS OF PATIENTS WITH MALIGNANT NEOPLASMS IN THE ORAL CAVITY $(\mathrm{N}=47)$

\begin{tabular}{|c|c|}
\hline Variable & $\begin{array}{l}\text { Oral cavity }(n=47) \\
n(\%)\end{array}$ \\
\hline $\begin{array}{l}\text { Gender } \\
\text { Men } \\
\text { Female }\end{array}$ & $\begin{array}{l}39(83.0) \\
8(17.0)\end{array}$ \\
\hline $\begin{array}{l}\text { Formal education } \\
\text { Up to } 8 \text { years } \\
\text { Over } 8 \text { years }\end{array}$ & $\begin{array}{l}26(55.3) \\
21(44.7) \\
\end{array}$ \\
\hline $\begin{array}{l}\text { Ethnicity } \\
\text { White } \\
\text { Black and Brown skinned }\end{array}$ & $\begin{array}{l}29(61.7) \\
18(38.3) \\
\end{array}$ \\
\hline $\begin{array}{l}\text { Marital status } \\
\text { With a spouse } \\
\text { Without a spouse } \\
\text { Unknown }\end{array}$ & $\begin{array}{l}25(55.6) \\
20(44.4) \\
2(4.3)\end{array}$ \\
\hline $\begin{array}{l}\text { Age at the time of the interview } \\
\leq 60 \text { years } \\
>60 \text { years }\end{array}$ & $\begin{array}{l}26(55.3) \\
21(44.7) \\
\end{array}$ \\
\hline $\begin{array}{l}\text { Time between surgery and interview } \\
\leq 2 \text { years } \\
>2 \text { years }\end{array}$ & $\begin{array}{l}25(53.2) \\
22(46.8)\end{array}$ \\
\hline $\begin{array}{l}\mathrm{T} \\
3 \\
4\end{array}$ & $\begin{array}{l}9(19.1) \\
38(80.9)\end{array}$ \\
\hline $\begin{array}{l}N \\
0 \\
1 \\
2 \\
3 \\
\end{array}$ & $\begin{array}{l}26(55.3) \\
9(19.2) \\
10(21.3) \\
2(4.2)\end{array}$ \\
\hline $\begin{array}{l}\text { Clinical Stage } \\
\text { III } \\
\text { IV }\end{array}$ & $\begin{array}{l}8(17.0) \\
39(83.0)\end{array}$ \\
\hline $\begin{array}{l}\text { Adjuvant radiotherapy } \\
\text { No } \\
\text { Yes } \\
\text { Radiotherapy + Chemotherapy }\end{array}$ & $\begin{array}{l}2(4.2) \\
42(89.4) \\
3(6.4)\end{array}$ \\
\hline
\end{tabular}

The frequency of the objective domains in the UW-QOL questionnaire can be found in Table 2 . The absence of pain was the most frequent answer for the pain domain (65.5\%). As for appearance, oral cancer patients reported being slightly bothered but still remaining active (34\%). Regarding activity, they reported being active most of the time (38.3\%). For recreation, most patients reported not having limitations for leaving home (46.5\%). The patients can only swallow some solid foods (38.3) and reported not being able to chew even light foods (55.3\%). In relation to the speech domain, most patients reported a bit of difficulty in speaking (64.8\%). Most patients reported no problems with the shoulder after the treatment $(64.8 \%)$. Regarding the domain of mood, the patients reported being usually in an excellent mood, unaffected by cancer (45.8\%). For the anxiety domain, most reported not being anxious as a result of cancer (59.2\%).
TABLE 2. FREQUENCY OF THE OBIECTIVE DOMAINS OF THE UW-QOL

\begin{tabular}{|c|c|c|}
\hline Domains & Categories & $n(\%)$ \\
\hline Pain & $\begin{array}{l}\text { Severe pain, uncontrolled by drugs } \\
\text { Severe pain controlled by prescription drugs } \\
\text { Moderate pain } \\
\text { Mild pain } \\
\text { Absence of pain }\end{array}$ & $\begin{array}{l}1(2.1) \\
1(2.1) \\
7(14.9) \\
11(23.4) \\
27(57.4)\end{array}$ \\
\hline $\begin{array}{l}\text { Appear- } \\
\text { ance }\end{array}$ & $\begin{array}{l}\text { Avoids social contact } \\
\text { Feels disfigured and limited } \\
\text { In slightly bothered, but active } \\
\text { Slight change } \\
\text { No change }\end{array}$ & $\begin{array}{l}1(2.1) \\
10(21.3) \\
16(34.0) \\
15(31.9) \\
5(10.6)\end{array}$ \\
\hline Activity & $\begin{array}{l}\text { Stays in bed and does not leave the house } \\
\text { Barely leaves the house, inactive } \\
\text { Slightly active, always tired } \\
\text { Mostly active } \\
\text { As active as always }\end{array}$ & $\begin{array}{l}0(0.0) \\
1(2.1) \\
13(27.7) \\
18(38.3) \\
15(31.9)\end{array}$ \\
\hline Recreation & $\begin{array}{l}\text { Does not leave the house, nothing is pleasant } \\
\text { Severe limitation, stays home } \\
\text { Would like to go out, but cannot } \\
\text { Few limitations, but still leaves the house } \\
\text { No limitations to leave the house }\end{array}$ & $\begin{array}{l}1(2.1) \\
8(17.0) \\
7(14.9) \\
9(19.1) \\
22(46.8)\end{array}$ \\
\hline $\begin{array}{l}\text { Swallow- } \\
\text { ing }\end{array}$ & $\begin{array}{l}\text { Cannot swallow } \\
\text { Can only swallow liquids } \\
\text { Can only swallow some solids } \\
\text { Can swallow well }\end{array}$ & $\begin{array}{l}2(4.3) \\
17(36.2) \\
18(38.3) \\
10(21.3)\end{array}$ \\
\hline Chewing & $\begin{array}{l}\text { Cannot chew anything } \\
\text { Chews light food } \\
\text { Chews light food and solids }\end{array}$ & $\begin{array}{l}26(55.3) \\
20(42.6) \\
1(2.1)\end{array}$ \\
\hline Speech & $\begin{array}{l}\text { Is not understood by others } \\
\text { Is understood only by the family and a few others } \\
\text { Slight difficulty to speak } \\
\text { Same speech as always }\end{array}$ & $\begin{array}{l}1(2.1) \\
5(10.6) \\
34(72.3) \\
7(14.9)\end{array}$ \\
\hline Shoulder & $\begin{array}{l}\text { Incapable of working } \\
\text { Pain and weakness, affects work } \\
\text { Hardened, does not affect activity } \\
\text { No shoulder problems }\end{array}$ & $\begin{array}{l}0(0.0) \\
9(19.1) \\
8(17.0) \\
30(63.8)\end{array}$ \\
\hline Taste & $\begin{array}{l}\text { Cannot taste anything } \\
\text { Tastes some things } \\
\text { Tastes most things } \\
\text { Tastes everything } \\
\end{array}$ & $\begin{array}{l}3(6.4) \\
11(23.4) \\
9(19.1) \\
24(51.1)\end{array}$ \\
\hline Saliva & $\begin{array}{l}\text { No saliva } \\
\text { Very little saliva } \\
\text { Enough } \\
\text { Normal saliva }\end{array}$ & $\begin{array}{l}6(12.8) \\
25(53.2) \\
5(10.6) \\
11(23.4)\end{array}$ \\
\hline Mood & $\begin{array}{l}\text { Extremely depressed due to cancer } \\
\text { Slightly depressed due to cancer } \\
\text { Indifferent } \\
\text { Good mood, only slightly affected due to cancer } \\
\text { Excellent, unaffected due to cancer }\end{array}$ & $\begin{array}{l}1(2.1) \\
11(23.4) \\
7(14.9) \\
13(27.7) \\
15(31.9)\end{array}$ \\
\hline Anxiety & $\begin{array}{l}\text { Very anxious due to cancer } \\
\text { Anxious due to cancer } \\
\text { Slightly anxious due to cancer } \\
\text { Not anxious due to cancer }\end{array}$ & $\begin{array}{l}5(10.6) \\
3(6.4) \\
18(38.3) \\
21(44.7)\end{array}$ \\
\hline
\end{tabular}

The variable of age at the time of the interview showed clinical and statistical significance in the domain of pain $(\mathrm{p}=0.049)$, with patients over 60 years old reporting better scores than those younger at the time of the interview. The marital status was statistically associated with quality of life in the saliva 
TABLE 3. AVERAGE FROM THE SCORES OF THE UW-QOL QUESTIONNAIRE DOMAINS, BY CLINICAL AND DEMOGRAPHIC VARIABLES OF PATIENTS WITH ADVANCED MALIGNANT NEOPLASMS IN THE ORAL CAVITY

\begin{tabular}{|c|c|c|c|c|c|c|c|c|c|c|c|c|c|c|}
\hline \multirow[t]{2}{*}{ Variable } & \multicolumn{2}{|l|}{ Pain } & \multicolumn{2}{|c|}{ Appearance } & \multicolumn{2}{|c|}{ Activity } & \multicolumn{2}{|c|}{ Recreation } & \multicolumn{2}{|c|}{ Swallowing } & \multicolumn{2}{|c|}{ Chewing } & \multicolumn{2}{|c|}{ Speech } \\
\hline & Average & $P$ value & Average & $P$ value & Average & $P$ value & Average & P value & Average & $P$ value & Average & P value & Average & P value \\
\hline $\begin{array}{l}\text { Gender } \\
\text { Men } \\
\text { Female }\end{array}$ & $\begin{array}{l}82.05 \\
87.50\end{array}$ & 0.563 & $\begin{array}{l}57.69 \\
53.13\end{array}$ & 0.641 & $\begin{array}{l}76.92 \\
65.63\end{array}$ & 0.165 & $\begin{array}{l}75.64 \\
59.38\end{array}$ & 0.176 & $\begin{array}{l}59.85 \\
54.13\end{array}$ & 0.606 & $\begin{array}{l}24.36 \\
18.75\end{array}$ & 0.602 & $\begin{array}{l}67.72 \\
62.75\end{array}$ & 0.522 \\
\hline $\begin{array}{l}\text { Age at the interview } \\
\leq 60 \text { years } \\
>60 \text { years }\end{array}$ & $\begin{array}{l}73.44 \\
87.90 \\
\end{array}$ & $0.049^{*}$ & $\begin{array}{l}60.94 \\
54.84 \\
\end{array}$ & 0.431 & $\begin{array}{l}78.12 \\
73.39 \\
\end{array}$ & 0.466 & $\begin{array}{l}73.44 \\
72.58 \\
\end{array}$ & 0.929 & $\begin{array}{l}58.37 \\
59.13 \\
\end{array}$ & 0.932 & $\begin{array}{l}25.00 \\
22.58\end{array}$ & 0.777 & $\begin{array}{l}71.06 \\
64.71 \\
\end{array}$ & 0.300 \\
\hline $\begin{array}{l}\text { Formal education } \\
\text { Up to } 8 \text { years } \\
\text { Over } 8 \text { years }\end{array}$ & $\begin{array}{l}79.81 \\
86.90 \\
\end{array}$ & 0.318 & $\begin{array}{l}58.65 \\
54.76 \\
\end{array}$ & 0.599 & $\begin{array}{l}76.92 \\
72.62 \\
\end{array}$ & 0.488 & $\begin{array}{l}75.96 \\
69.05 \\
\end{array}$ & 0.450 & $\begin{array}{l}57.69 \\
60.33 \\
\end{array}$ & 0.753 & $\begin{array}{l}23.08 \\
23.81\end{array}$ & 0.928 & $\begin{array}{l}66.85 \\
66.90\end{array}$ & 0.992 \\
\hline $\begin{array}{l}\text { Ethnicity } \\
\text { White } \\
\text { Black and Brown skinned }\end{array}$ & $\begin{array}{l}81.03 \\
86.11 \\
\end{array}$ & 0.486 & $\begin{array}{l}56.90 \\
56.94 \\
\end{array}$ & 0.995 & $\begin{array}{l}75.00 \\
75.00 \\
\end{array}$ & 1.000 & $\begin{array}{l}75.00 \\
69.44\end{array}$ & 0.553 & $\begin{array}{l}64.38 \\
50.00\end{array}$ & 0.089 & \begin{tabular}{|l}
25.86 \\
19.44 \\
\end{tabular} & 0.439 & $\begin{array}{l}66.90 \\
66.83\end{array}$ & 0.992 \\
\hline $\begin{array}{l}\text { Marital status } \\
\text { With a spouse } \\
\text { Without a spouse }\end{array}$ & $\begin{array}{l}80.00 \\
87.50\end{array}$ & 0.300 & $\begin{array}{l}52.00 \\
65.00\end{array}$ & 0.082 & $\begin{array}{l}73.00 \\
77.50\end{array}$ & 0.488 & $\begin{array}{l}70.00 \\
77.50\end{array}$ & 0.416 & $\begin{array}{l}61.32 \\
55.00\end{array}$ & 0.469 & $\begin{array}{l}24.00 \\
20.00\end{array}$ & 0.631 & $\begin{array}{l}64.24 \\
70.15\end{array}$ & 0.334 \\
\hline $\begin{array}{l}\text { Clinical Stage } \\
\text { III } \\
\text { IV }\end{array}$ & $\begin{array}{l}81.25 \\
83.33 \\
\end{array}$ & 0.825 & $\begin{array}{l}71.88 \\
53.85 \\
\end{array}$ & 0.061 & $\begin{array}{l}81.25 \\
73.72 \\
\end{array}$ & 0.358 & $\begin{array}{l}93.75 \\
68.59 \\
\end{array}$ & $0.034^{*}$ & $\begin{array}{l}66.87 \\
57.23 \\
\end{array}$ & 0.383 & $\begin{array}{l}25.00 \\
23.08\end{array}$ & 0.858 & $\begin{array}{l}71.13 \\
66.00\end{array}$ & 0.509 \\
\hline $\begin{array}{l}\text { Site } \\
\text { Tongue } \\
\text { Glngival margin }\end{array}$ & $\begin{array}{l}87.07 \\
76.39 \\
\end{array}$ & 0.139 & $\begin{array}{l}62.93 \\
47.22 \\
\end{array}$ & $0.033^{*}$ & $\begin{array}{l}77.59 \\
70.83\end{array}$ & 0.285 & $\begin{array}{l}79.39 \\
72.50 \\
\end{array}$ & 0.068 & $\begin{array}{l}60.90 \\
55.61\end{array}$ & 0.537 & $\begin{array}{l}24.14 \\
22.22\end{array}$ & 0.818 & $\begin{array}{l}63.41 \\
72.44 \\
\end{array}$ & 0.128 \\
\hline $\begin{array}{l}\text { Time of surgery/interview } \\
\leq 2 \text { years } \\
>2 \text { years }\end{array}$ & $\begin{array}{l}76.00 \\
90.91 \\
\end{array}$ & $0.032^{\star}$ & $\begin{array}{l}52.00 \\
62.50 \\
\end{array}$ & 0.150 & $\begin{array}{l}73.00 \\
77.27 \\
\end{array}$ & 0.489 & $\begin{array}{l}64.00 \\
82.95\end{array}$ & $0.034^{*}$ & $\begin{array}{l}60.00 \\
57.59\end{array}$ & 0.773 & $\begin{array}{l}28.00 \\
18.18\end{array}$ & 0.222 & $\begin{array}{l}61.52 \\
72.95\end{array}$ & $0.046^{*}$ \\
\hline $\begin{array}{l}\text { Reconstruction } \\
\text { Myocutaneous flap/no } \\
\text { Free flap }\end{array}$ & $\begin{array}{l}82.81 \\
75.00\end{array}$ & 0.287 & $\begin{array}{l}51.56 \\
59.62\end{array}$ & 0.580 & $\begin{array}{l}67.19 \\
75.00\end{array}$ & $0.119^{\star \star}$ & $\begin{array}{l}70.31 \\
69.23\end{array}$ & 0.696 & $\begin{array}{l}54.13 \\
53.92\end{array}$ & 0.334 & $\begin{array}{l}25.00 \\
23.08\end{array}$ & 0.958 & $\begin{array}{l}69.00 \\
64.31\end{array}$ & 0.823 \\
\hline
\end{tabular}

TABLE 3 - CONTINUED AVERAGE FROM THE SCORES OF THE UW-QOL QUESTIONNAIRE DOMAINS, BY CLINICAL AND DEMOGRAPHIC VARIABLES OF PATIENTS WITH ADVANCED MALIGNANT NEOPLASMS IN THE ORAL CAVITY

\begin{tabular}{|c|c|c|c|c|c|c|c|c|c|c|c|c|}
\hline \multirow[t]{2}{*}{ Variable } & \multicolumn{2}{|c|}{ Shoulder } & \multicolumn{2}{|l|}{ Taste } & \multicolumn{2}{|l|}{ Saliva } & \multicolumn{2}{|l|}{ Mood } & \multicolumn{2}{|c|}{ Anxiety } & \multicolumn{2}{|c|}{ Composite score } \\
\hline & Average & P value & Average & P value & Average & P value & Average & Pvalue & Average & Pvalue & Average & Pvalue \\
\hline $\begin{array}{l}\text { Gender } \\
\text { Men } \\
\text { Female }\end{array}$ & $\begin{array}{l}80.33 \\
87.50\end{array}$ & 0.497 & $\begin{array}{l}75.23 \\
54.00\end{array}$ & 0.102 & $\begin{array}{l}52.03 \\
28.88\end{array}$ & 0.073 & $\begin{array}{l}67.95 \\
56.25\end{array}$ & 0.330 & $\begin{array}{l}74.46 \\
62.63\end{array}$ & 0.348 & $\begin{array}{l}66.00 \\
57.54\end{array}$ & 0.142 \\
\hline $\begin{array}{l}\text { Age at the interview } \\
\leq 60 \text { years } \\
>60 \text { years }\end{array}$ & $\begin{array}{l}85.44 \\
79.55\end{array}$ & 0.482 & $\begin{array}{l}75.06 \\
69.84\end{array}$ & 0.617 & $\begin{array}{l}58.25 \\
42.84\end{array}$ & 0.134 & $\begin{array}{l}70.31 \\
63.71\end{array}$ & 0.489 & $\begin{array}{l}75.13 \\
71.06\end{array}$ & 0.686 & $\begin{array}{l}67.04 \\
63.28\end{array}$ & 0.413 \\
\hline $\begin{array}{l}\text { Formal education } \\
\text { Up to } 8 \text { years } \\
\text { Over } 8 \text { years }\end{array}$ & $\begin{array}{l}82.08 \\
80.90\end{array}$ & 0.884 & $\begin{array}{l}79.50 \\
61.86 \\
\end{array}$ & 0.071 & $\begin{array}{l}53.73 \\
41.10 \\
\end{array}$ & 0.199 & $\begin{array}{l}66.35 \\
65.48 \\
\end{array}$ & 0.924 & $\begin{array}{l}75.73 \\
68.38 \\
\end{array}$ & 0.441 & $\begin{array}{l}66.12 \\
62.62 \\
\end{array}$ & 0.426 \\
\hline $\begin{array}{l}\text { Ethnicity } \\
\text { White } \\
\text { Black and Brown skinned }\end{array}$ & $\begin{array}{l}81.59 \\
81.50 \\
\end{array}$ & 0.992 & $\begin{array}{l}68.93 \\
75.94 \\
\end{array}$ & 0.490 & $\begin{array}{l}51.59 \\
42.44 \\
\end{array}$ & 0.336 & $\begin{array}{l}68.10 \\
62.50 \\
\end{array}$ & 0.547 & $\begin{array}{l}73.66 \\
70.50 \\
\end{array}$ & 0.747 & $\begin{array}{l}65.74 \\
62.65 \\
\end{array}$ & 0.492 \\
\hline $\begin{array}{l}\text { Marital status } \\
\text { With a spouse } \\
\text { Without a spouse }\end{array}$ & $\begin{array}{l}76.00 \\
90.00 \\
\end{array}$ & 0.075 & $\begin{array}{l}74.68 \\
68.30 \\
\end{array}$ & 0.530 & $\begin{array}{l}38.48 \\
58.25\end{array}$ & $0.045^{*}$ & $\begin{array}{l}61.0 \\
72.50 \\
\end{array}$ & 0.208 & $\begin{array}{l}72.12 \\
71.75 \\
\end{array}$ & 0.970 & $\begin{array}{l}62.20 \\
67.47\end{array}$ & 0.248 \\
\hline $\begin{array}{l}\text { Clinical Stage } \\
\text { III } \\
\text { IV }\end{array}$ & $\begin{array}{l}83.38 \\
81.18\end{array}$ & 0.836 & $\begin{array}{l}70.75 \\
71.79\end{array}$ & 0.937 & $\begin{array}{l}49.88 \\
47.72\end{array}$ & 0.870 & $\begin{array}{l}78.13 \\
63.46\end{array}$ & 0.220 & $\begin{array}{l}79.25 \\
71.05\end{array}$ & 0.516 & $\begin{array}{l}71.04 \\
63.23\end{array}$ & 0.176 \\
\hline $\begin{array}{l}\text { Site } \\
\text { Tongue } \\
\text { Glngival margin }\end{array}$ & $\begin{array}{l}79.31 \\
85.17 \\
\end{array}$ & 0.473 & $\begin{array}{l}74.72 \\
66.61\end{array}$ & 0.424 & $\begin{array}{l}57.31 \\
33.22 \\
\end{array}$ & $0.014^{*}$ & $\begin{array}{l}66.38 \\
65.28 \\
\end{array}$ & 0.906 & $\begin{array}{l}73.69 \\
70.44\end{array}$ & 0.740 & $\begin{array}{l}67.20 \\
60.31 \\
\end{array}$ & 0.121 \\
\hline $\begin{array}{l}\text { Time of surgery/interview } \\
\leq 2 \text { years } \\
>2 \text { years }\end{array}$ & $\begin{array}{l}75.96 \\
87.91\end{array}$ & 0.129 & $\begin{array}{l}60.00 \\
84.82\end{array}$ & $0.009^{*}$ & $\begin{array}{l}49.16 \\
46.86\end{array}$ & 0.816 & $\begin{array}{l}59.00 \\
73.86\end{array}$ & 0.097 & $\begin{array}{l}61.48 \\
84.91\end{array}$ & $0.011^{\star}$ & $\begin{array}{l}60.01 \\
69.73\end{array}$ & $0.023^{*}$ \\
\hline $\begin{array}{l}\text { Reconstruction } \\
\text { Myocutaneous flap/no } \\
\text { Free flap }\end{array}$ & $\begin{array}{l}81.50 \\
79.46 \\
\end{array}$ & 0.932 & $\begin{array}{l}77.78 \\
74.38 \\
\end{array}$ & 0.393 & $\begin{array}{l}51.72 \\
51.16 \\
\end{array}$ & 0.632 & \begin{tabular}{|l}
68.06 \\
67.96 \\
\end{tabular} & 0.860 & $\begin{array}{l}72.33 \\
64.31 \\
\end{array}$ & 0.472 & $\begin{array}{l}67.95 \\
63.06 \\
\end{array}$ & 0.464 \\
\hline
\end{tabular}

${ }^{*}$ Corresponds to values with clinical significance (a difference of 7 points in score and $p<0.05$ ). 
domain ( $\mathrm{p}=0.045)$ and clinically associated with the appearance and shoulder domains. Patients in clinical stage III presented better clinical scores than those in stage IV, showing statistical significance in the field of recreation $(\mathrm{p}=0.034)$. Patients with over two years of difference between the time of the interview and the time of the surgery presented better quality of life scores than those with less than 2 years of difference, with statistical significance for the domains of pain $(p=0.032)$, recreation $(p=0.034)$, speech $(p=0.046)$, taste $(p=0.009)$, anxiety $(p=0.011)$, and composite score $(p=0.023)$. The average from the scores of the UW-QOL questionnaire domains, by clinical and demographic variables of patients with advanced malignant neoplasms in the oral cavity, can be found in Table 3 .

The only variable of the composite quality of life score included in the linear regression model was time between surgery and interview, with those with under two years presenting a lower composite score (coefficient of -9.73, 95\% CI -18.016 -1.435, $\mathrm{p}=0.023$ ). The model expressed a score of $9 \%$ for quality of life in that population $(\mathrm{r} 2=0.091)$.

\section{DISCUSSION}

Advanced malignant neoplasms of the head and neck and its extensive treatments, associated with adjuvant radiotherapy, may result in significant dysfunction, such as in chewing, swallowing and speech. Our results show that these individuals have an epidemiological profile similar to those present in other Brazilian studies. ${ }^{6}$ The average age of the population studied was over 50 years, and most individuals were men, with low levels of formal education, white, who lived with their spouses, presented clinical stage level IV, and underwent radiotherapy.

Still regarding the studies by Vartanian and Kowalski $^{6}$, advanced stage patients, with over 5 years of survival, reported good quality of life, a result compatible with the one found in this study. Patients with survival over 12 months who took the questionnaire presented higher scores. This finding can be due to a greater time to adapt to the repercussions of treatment.

Studies with positive results for quality of life in patients who underwent mandible reconstruction with fibula were conducted in patients with benign disease, for which treatment required resection with less damage to the soft tissues ${ }^{3}$, unlike the cases in this study.
As for the global parts of the questionnaire, $47.2 \%$ of patients considered their quality of life to be good overall, and $57.8 \%$ considered their health to be the same or better than it was before the treatment. These results differ from those found by Vartanian and Kowalski ${ }^{6}$, in which $59.3 \%$ of the patients considered their quality of life to be from good to excellent ,and $74.0 \%$ to be the same or better. This study included a broader variety of sites and stages of the disease, which might have affected the results.

As for the comparative questions, it was found that quality of life was the same (31.9\%) when compared to a time prior to the disease or slightly better (38.3\%) after the treatment. In general, patients considered their quality of life to be from average (23.4\%) to $\operatorname{good}(48.9 \%)$.

There is no data indicating if cultural aspects influenced these results. However, according to Vartanian and Kowalski ${ }^{6}$, patients from developing countries and with difficult access to healthcare are usually more grateful to doctors and try not to disappoint them, despite the assured confidentiality. That might explain the high level of satisfaction present in the global questions.

This study followed the guidelines of Weymuller et al. ${ }^{7}$ for researches in a single institution, with the recommendation of cross-sectional studies in which the survivors can be assessed in a single application of the questionnaire and also in a cohort that represents the majority of cases in the institution.

During the screening of eligible cases, out of the total 183 oral cancer patients, 47 were alive after less than five years. In a similar study ${ }^{8}$. it was found that even with surgical treatment and adjuvant radiotherapy, only the minority of patients were cured and less than 30\% survived after five years. It was not possible to include more patients, which might have had a negative influence on the results. However, a small number was also reported in an American retrospective study over 25 years that found only 26 patients alive, out of which only 26 could be assessed. ${ }^{9}$

No link was found between any of the UW-QOL domains and the type of reconstruction undergone by the advanced oral cancer patients, contrary to what was initially expected. The impossibility of bone reconstruction generates the greater functional and aesthetic defect. The sample size might have affected these results, a difficulty also reported by similar studies. ${ }^{9}$ 
According to the findings of Vartanian and Kowals$\mathrm{ki}^{10}$, patients under 60 years old reported worse scores and increased complaints about pain when compared to those younger, which was inconsistent to the finding of another Spanish study, in which individuals under 60 years old had better results in the early stages group of patients. ${ }^{11}$ Stage III individuals showed better scores than those in stage IV, in line with the findings of the same study by López-Jornet et al. ${ }^{11}$ In the recreation domain, stage IV patients presented greater difficulties in leaving the house and having contact due to greater aesthetic-functional sequelae.

In view of the results discussed, it is evident that the incorporation of quality of life analysis in clinical practice is of great relevance, for it allows for the assessment of treatments and its sequelae. Its adoption in everyday practice and the presence of a qualified and cohesive multidisciplinary team allows for the thorough care of patients and their family. Furthermore, the knowledge of the most affected domains makes t possible to have a proper approach to the needs of the patients, allowing them a better quality of life.

The fact that the study was conducted using a homogeneous population from a single institution with data collected by a single researcher increases its internal validity since it minimizes selection and measurement biases of both outcome and independent variables. However, due to the characteristics previously mentioned, the applicability of these data in other populations with a different profile is arguable. Nonetheless, our results were similar to those found in literature. ${ }^{12}$

A limitation of the cross-sectional study is its use of the surviving population, for its results may not be representative of the entire population subject to the treatment. Even though the measurement of quality of life after the treatment can be considered limiting, for these individuals could present a lower score at the moment of diagnosis, the author who validated the questionnaire affirms that this is the best way to apply it in cross-sectional studies. ${ }^{7}$

In conclusion, there was no statistically significant difference among domains of quality of life between both groups studied (with bone reconstruction versus without bone reconstruction). Patients interviewed at least two years after the treatment presented higher scores on quality of life. Our results were able to describe general aspects of quality of life in this population, which can be used to plan and assess strategies used in patients who undergo oral cancer treatment.

\section{RESUMO}

INTRODUÇão: As neoplasias malignas de cabeça e pescoço, pela própria localização anatômica, podem acarretar alterações significativas em funções vitais relacionadas à alimentação, comunicação e interação social dos indivíduos afetados.

OBJETIVO: Analisar a qualidade de vida dos pacientes com neoplasias malignas avançadas de cavidade oral, submetidos a operações radicais com intenção curativa.

MATERIAL E MÉTODOS: 47 pacientes portadores de carcinoma espinocelular de cavidade oral, em estádios III e IV, foram submetidos ao tratamento cirúrgico com mandibulectomia segmentar e radioterapia complementar. Os pacientes foram submetidos ao teste de qualidade de vida após o tempo mínimo de seis meses do tratamento cirúrgico.

RESULTADOS: Dos 183 pacientes, com apenas 47 (25,7\%) foi possível a realização da entrevista, compondo estes a amostra para o estudo. A maioria dos pacientes do grupo selecionado era do sexo masculino, total de 39 homens (82,9\%). A idade média foi de 64,4 anos. A maioria dos pacientes apresentava estadiamento clínico IV (83\%), sendo submetidos à radioterapia adjuvante (95,4\%). A média do escore obtido após a avaliação dos questionários foi de 64,6. Os piores escores foram encontrados nos quesitos deglutição e mastigação. CONCLUSÃo: Não houve diferenças estatisticamente significativas nos domínios de qualidade de vida entre os dois grupos estudados (com reconstrução óssea versus sem reconstrução óssea). Pacientes entrevistados dois anos ou mais após o tratamento apresentaram escores superiores $(p=0,02)$.

PALAVRAS-CHAVE: Qualidade de vida. Neoplasias bucais. Reconstrução mandibular. Carcinoma de células escamosas. Transplante ósseo. Osteotomia mandibular.

\section{REFERENCES}

1. Nemoto RP, Victorino AA, Pessoa GB, Cunha LL, Silva JA, Kanda JL, et al. Oral cancer preventive campaigns: are we reaching the real target? Braz J Otorhinolaryngol. 2015;81(1):44-9.

2. Rigoni L, Bruhn RF, De Cicco R, Kanda JL, Matos LL. Quality of life impairment in patients with head and neck cancer and their caregivers: a comparative study. Braz J Otorhinolaryngol. 2016;82(6):680-6.
3. Li X, Zhu K, Liu F, Li H. Assessment of quality of life in giant ameloblastoma adolescent patients who have had mandible defects reconstructed with a free fibula flap. World J Surg Oncol. 2014;12:201.

4. Lin CS, Oliveira Santos AB, Silva EL, Matos LL, Moyses RA, Kulcsar MA, et al. Tumor volume as an independent predictive factor of worse survival in patients with oral cavity squamous cell carcinoma. Head Neck. 2017;39(5):960-4. 
5. Vartanian JG, Carvalho AL, Furia CLB, Castro Jr G, Rocha CN, Sinitcovisky IML, et al. Questionários para a avaliação de Qualidade de Vida em pacientes com câncer de cabeça e pescoço validados no Brasil. Rev Bras Cir Cabeça Pescoço. 2007;36(2):108-15

6. Vartanian JG, Kowalski LP. Acceptance of major surgical procedures and quality of life among long-term survivors of advanced head and neck cancer. Arch Otolaryngol Head Neck Surg. 2009;135(4):376-9.

7. Weymuller EA, Yueh B, Deleyiannis FW, Kuntz AL, Alsarraf R, Coltrera MD. Quality of life in patients with head and neck cancer: lessons learned from 549 prospectively evaluated patients. Arch Otolaryngol Head Neck Surg. 2000;126(3):329-35.

8. Sanabria A, Carvalho AL, Vartanian JG, Magrin J, Ikeda MK, Kowalski LP. Factors that influence treatment decision in older patients with resectable head and neck cancer. Laryngoscope. 2007;117(5):835-40.
9. Thomas L, Moore EJ, Olsen KD, Kasperbauer JL. Long-term quality of life in young adults treated for oral cavity squamous cell cancer. Ann Otol Rhinol Laryngol. 2012;121(6):395-401.

10. Vartanian |G, Carvalho AL, de Araújo Filho MJ, Junior MH, Magrin |, Kowalski LP. Predictive factors and distribution of lymph node metastasis in lip cancer patients and their implications on the treatment of the neck. Oral Oncol. 2004;40(2):223-7.

11. López-Jornet P, Camacho-Alonso F, López-Tortosa J, Palazon Tovar T, Rodríguez-Gonzales MA. Assessing quality of life in patients with head and neck cancer in Spain by means of EORTC QLQ-C30 and QLQ-H\&N35. J Craniomaxillofac Surg. 2012;40(7):614-20.

12. Silveira A, Gonçalves I, Sequeira T, Ribeiro C, Lopes C, Monteiro E, et al. Head and neck cancer: health related quality of life assessment considering clinical and epidemiological perspectives. Rev Bras Epidemiol. 2012;15(1):38-48 